\title{
Analisis Pendapatan Usaha Kecil dan Menengah Yogurt Sehati Purwokerto
}

\section{Income Analysis of Small and Medium Enterprises of Yogurt Sehati Purwokerto}

\author{
Siti Mudmainah ${ }^{1 *}$, Yukhsan Wakhyudi \\ Fakultas Sains dan Teknoogi Universitas Peradaban Bumiayu, Jl. Raya Pagojengan KM 3 Paguyangan \\ Brebes Jawa Tengah
}

Received: 24 January 2019; Revised: 25 January 2019; Accepted: 29 January 2019

\begin{abstract}
ABSTRAK
Yogurt sebagai salah satu produk olahan susu sudah banyak beredar dan diproduksi oleh industry besar, maupun industry rumah tangga/UKM. Pengembangan UKM yogurt membuka peluang untuk meningkatkan pendapatan rumah tangga dan kesejahteraan. Tujuan kegiatan ini adalah mennganalisis pendapatan UKM yogurt Sehati yang telah mendapatkan pendampingan melalui transfer pengetahuan dan ketrampilan dalam pengolahan susu menjadi produk yoghurt dengan berbagai varians kemasan. Penelitian ini dilaksanakan di UKM Yogurt SEHATI yang berlokasi di Keluarahan Purwonegoro, Kecamatan Purwokerto Utara Kabupaten Banyumas, Jawa Tengah dari bulan Maret sampai dengan Juli 2017. Model penelitian ini adalah penelitian aksi yakni dengan melakukan tindakan intervensi langsung terhadap obyek penelitian melalui transfer teknologi, kemudian diukur perubahan dari sisi income setelah proses transfer teknologi. Hasil kegiatan menunjukkan adanya perubahan income dan praktik dalam produksi yogurt dengan berbagai varians rasa dan kemasan. Terjadi peningkatan volume produksi yogurt rata-rata dari $5 \mathrm{~L}$ per hari meningkat menjadi $25 \mathrm{~L}$ perhari dengan variasi produk bermacam-macam. Perubahan kemasan produk berpengaruh positif terhadap persepsi dan minat konsumen yogurt. Perluasan jaringan pemasaran dilakukan dengan menggunakan system pemasaran online dengan menggunakan media sosial dan fanpage facebook. Berdasarkan analisis pendapatan diperoleh nilai keuntungan bersih Rp 26.776.943/tahun. Analisis efisiensi usaha menunjukkan nilai $\mathrm{R} / \mathrm{C}$ ratio sebesar 1,07 dimana setiap $\mathrm{Rp} 1.000$ atas biaya keseluruhan yang dikeluarkan maka akan memberikan penerimaan sebesar Rp 1.070 sehingga usaha tersebut layak untuk dijalankan karena jumlah penerimaan yang lebih besar dari biaya total.
\end{abstract}

Kata kunci: yogurt; rasa; kemasan; UKM; purwokerto; analisis pendapatan

\begin{abstract}
Yogurt as one of the processed dairy products has been widely circulated and produced by large industries, as well as home industries / SMEs. The development of UKM yogurt opens opportunities to increase household income and welfare. The purpose of this activity was to analyze the income of UKM UKM Sehati who has received assistance through the transfer of knowledge and skills in processing milk into yogurt products with various packaging variances. This research was carried out in SEHATI Yogurt located in Purwonegoro Subdistrict, North Purwokerto Subdistrict, Banyumas Regency, Central Java from March to July 2017. This research model was an action research that was by direct intervention to the object of research through technology transfer, then measured changes in terms of income after the technology transfer process. The results of the activity showed a change in income and practice in the production of yogurt with various flavor and packaging variances. An increase in the volume of yogurt production averages from $5 \mathrm{~L}$ per day to $25 \mathrm{~L}$ per day with a variety of products. Changes in product packaging have a positive effect on consumers' perceptions and interests of yogurt. The expansion of network marketing is done by using an online marketing system using social media and Facebook fanpage. Based on the income analysis, the net profit value of Rp. 26,776,943 / year was obtained. Business efficiency analysis shows the value of $R / C$ ratio of 1.07 where every $R p .1,000$ for the overall costs incurred will provide revenues of $R p .1,070$ so that the business is feasible because the amount of revenue is greater than the total cost.
\end{abstract}

Key words: yogurt; packaging; diversification; SMEs.Purwokerto; income analysis

How to Cite:

Mudmainah, S., \& Wakhyudi, Y. (2019). Analisis Pendapatan Usaha Kecil dan Menengah Yogurt Sehati Purwokerto. HABITAT, 30(1), 16-25. https://doi.org/10.21776/ub.habitat.2019.030.1.3 


\section{Pendahuluan}

Produk olahan susu saat ini mengalami perkembangan produksi yang sangat pesat seiring dengan meningkatnya kesadaran masyarakat akan asupan gizi yang seimbang. Berbagai jenis olahan susu sudah beredar di pasaran dan dengan harga yang terjangkau seperti susu pasteurisasi, susu UHT, keju dan yogurt. Susu fermentasi atau lebih dikenal dengan nama Yogurt merupakan produk olahan susu hasil fermentasi oleh bakteri Streptococcus thermophilus dan Lactobacillus bulgaricus yang menghasilkan konsistensi menyerupai pudding (Mistura, et.al., 2016; Resnawati, 2015). Penambahan bakteri berguna dalam olahan yogurt akan memperbaiki tingkat kesehatan organ pencernaan. Menurut Koswara (2009) keuntungan pengolahan susu secara fermentasi antara lain perbaikan nilai gizi, keseimbangan microflora usus, menurunkan kolesterol, dan pencegahan kanker (Zhu et al., 2015). Komposisi nutrisi yang terkandung dalam yogurt lebih tinggi dibanding dalam susu murni terutama kadar riboflavin, vitamin B12, calcium, magnesium, dan potassium (Freitas, 2017). Lebih lanjut Fernandez et al., (2017) menyatakan bahwa kandungan nutrisi yogurt sangat padat dan merupakan sumber nutrisi baik makro maupun mikro serta protein berkualitas tingg dan karbohidrat yang mudah dicerna.

Inovasi pengembangan produk yogurt saat ini tidak hanya pada pengkayaan bakteri berguna pada yoghurt tetapi juga memperbaiki sifat sensorik dan umur simpan yoghurt. Yogurt sebagai hasil fermentasi susu citarasa yogurt pada umumnya asam yang kurang disukai olah konsumen. Citarasa asam yogurt yang berasal dari laktosa dalam susu yang diubah menjadi asam laktat oleh bakteri asam laktat selama proses fermentasi berlangsung akan meningkatkan keasaman susu, sehingga menyebabkan yogurt memiliki rasa asam (Ariuoi, et al., 2017; Jannah et al., 2014). Perbaikan sifat sensorik dengan penambahan cita rasa akan meningkatkan kesukaan konsumen terhadap yoghurt. Menurut Zhao al.,(2018) raasa merupakan salah satu faktor terpenting yang menentukan penerimaan konsument terhadap produk yoghurt.

Yoghurt sebagai salah satu produk olahan susu sudah banyak beredar dan diproduksi oleh industri besar, maupun industri rumah

"Penulis Korespondensi.

E-mail: nasutionmanis@gmail.com
tangga/UKM. Pengembangan UKM yoghurt membuka peluang untuk meningkatkan pendapatan rumah tangga dan kesejahteraan. UKM yogurt biasanya memproduksi yoghurt murni, maupun yoghurt beku yang dipasarkan pada skala local (Rahayu et. Al., 2014).

UKM Yoghurt Sehati merupakan usaha pengolahan susu menjadi produk yoghurt skala rumah tangga yang mulai usaha sejak 1 Januari 2016 dengan pemilik Ibu Sukesti. Yoghurt Sehati beralamat di Kelurahan Purwonegoro RT 05/VI Purwokerto Utara. Sebagai usaha kecil skala rumah tangga, jalannya usaha masih dikelola secara manajemen keluarga dengan tenaga kerja produksi sebanyak 2 orang, dan tidak ada pembagian kerja yang jelas. Semua kegiatan produksi dari pengadaan bahan baku, produksi, dan pemasaran masih dilakukan secara konvensional. Oleh sebab itu, perlu dianalisis besarnya nilai pendapatan yang dapat dihasilkan dari produksi UKM Yoghurt tersebut beserta diversifikasi produknya.

Bahan baku susu segar diperoleh dari Peternakan sapi di Baturaden, dan starter yoghurt diperoleh dari Starter dari Raja Yogurt Bandung. Kapasitas produksi saat ini baru mencapai 10 L/hari. Kecilnya volume produksi disebabkan incubator untuk fermentasi yoghurt masih seadanya dengan menggunakan steroform box dengan kapasitas $5 \mathrm{~L}$, sehingga untuk mencapai kondisi lingkungan yang optimal untuk menghasilkan yoghurt premium sangat sulit dicapai. Kualitas yoghurt yang baik akan dihasilkan dari proses fermentasi pada suhu $38^{\circ}$ $43^{\circ} \mathrm{C}$. Idealnya untuk mencapai kapasitas produksi yang lebih besar dengan kualitas baik, proses fermentasi susu dilakukan dengan menggunakan fermentor semioutomatis dengan temperature control yang baik (Meng et al., 2018).

Produk yang dihasilkan berupa yoghurt murni yang dikemas dalam botol @ 250 mL dengan labelling yang sangat sederhana, dan yoghurt rasa sesuai permintaan dengan harga jual@Rp. 7.000,-. Varian kemasan saat ini baru terbatas dalam botol tersebut, sehingga untuk melayani konsumen dengan daya beli lebih rendah masih sulit dilayani. Disisi lain, penambahan cita rasa yang saat ini dilakukan belum diperoleh perbandingan yang tepat sehingga rasa yang dihasilkan belum tepat dan terkadang ada complain dari konsumen. Penambahan citarasa dengan takaran yang tidak tepat dapat menurunkan nilai kesukaan konsumen. Riset aksi ini dengan demikian bertujuan untuk meningkatkan pengetahuan dan ketrampilan 
dalam pengolahan susu menjadi produk yoghurt, meningkatkan kualitas dan jumlah varian produk yogurt, meningkatkan volume produksi, dan perbaikan kemasan produk yogurt.

\section{Metode Pelaksanaan}

\subsection{Pendekatan Penelitian}

Penelitian ini termasuk action research, yaitu penelitian yang menggabungkan teori dan praktek. Menurut O'brien (2002), action research bertujuan untuk berkontribusi pada praktis kepedulian terhadap permasalahan masyarakat saat ini dan juga untuk mencapai sasaran-sasaran ilmu sosial secara bersamaan. Penelitian ini tergolong penelitian aksi yang berpartisipasi atau dikenal dengan Partisipatory Action Researh (PAR). Gillis dan Jacson, 2002;264) mengatakan PAR is considered a subset of action research, which is the "systematic collection and analysis of data for the purpose of taking action and making change" by generating practical knowledge.

Pendekatan penelitian yang digunakan dalam penelitian ini adalah mixing method, yaitu kombinasi antara penelitian kualitatif dan kuantitatif. Menurut Ivankova (2015), mixing method sangat realistik untuk diterapkan pada action research. Hal ini karena terdapat beberapa karakteristik dari mixing method dan action research yang membuka cukup ruang integrasi implementasi mixed method dalam action research. Karakteristik yang dimaksud seperti implementasi penelitian berbasis permasalahan yang sistematis, penggunaan sumber data (kualitatif dan kuantitatif), dan pemanfaatan IPTEK dalam pencarian solusi permasalahan.

Penelitian ini tergolong penelitian aksi yang berpartisipasi atau dikenal dengan Partisipatory Action Researh (PAR). Gillis dan Jacson, 2002;264) mengatakan PAR is considered a subset of action research, which is the "systematic collection and analysis of data for the purpose of taking action and making change" by generating practical knowledge. Jadi usaha yang dilakukan oleh peneliti adalah melakukan generalisasi atas pengetahuan yang diperoleh dari praktek yang dilakukan, dalam hal ini adalah pengetahuan yang diperoleh dari implementasi introdusir teknologi.

Fokus penelitian terpusat di UKM Yogurt SEHATI yang berlokasi di Keluarahan Purwonegoro, Kecamatan Purwokerto Utara Kabupaten Banyumas, Jawa Tengah dari bulan Maret sampai dengan Juli 2017. Intervensi yang dilakukan untuk mengatasi permasalahan mitra dengan transfer teknologi melalui proses alih teknologi, pelatihan, pecontohan produksi (demplot), pendampingan manajemen dan produksi. Alih teknologi dilakukan dengan metode ceramah dan diskusi yang bersifat interaktif dan berlangsung dua arah. Metode ini merupakan inisiasi program dengan harapan mitra UKM yoghurt mempunyai pengetahuan dasar yang baik tentang teknologi pengolahan susu yang baik untuk menghasilkan yoghurt dengan kualitas premium. Penerapan program selanjutnya dengan peningkatan ketrampilan mitra melalui pelatihan dilengkapi dengan demplot.

Percontohan produksi yoghurt dikelola langsung oleh mitra dengan pendampingan teknis yang tepat, sehingga diharapkan transfer dan adopsi teknologi dapat diserap secara penuh oleh mitra. Sebagai pembanding transfer teknologi, dibuat demplot pembanding yaitu demplot kontrol yaitu teknologi produksi yoghurt yang biasa dilakukan mitra. Aplikasi teknologi yang telah dicontohkan oleh tim pelaksana IbM kemudian diupayakan langsung oleh mitra sendiri secara berkesinambungan. Sementara itu, untuk kegiatan obeservasi berpartisipasi, analisis ekonomi sederhana kami lakukan untuk menganalisis kelayakan dari intervensi yang kami lakukann tersebut.

\subsection{Metode Analisis Data}

Analisis pendapatan digunakan untuk menganalisis besarnya keuntungan atau pendapatan yang diperoleh dari suatu jenis usaha (Soekartawi, 2006). Analisis pendapatan dapat dipakai untuk melihat seberapa besar keberhasilan kegiatan usaha dan sebagai tolak ukur dalam merancang keadaan di masa mendatang. Besarnya nilai pendapatan diperoleh dari selisih antara total biaya dan penerimaan pada usaha tersebut. Menurut Soekartawi (2006), biaya (cost) merupakan semua pengeluaran yang dipergunakan dalam suatu usaha. Dalam hal ini, biaya dikelompokkan menjadi 2, yakni biaya tetap dan biaya variabel. Biaya tetap (fixed cost) adalah biaya yang nilainya tidak berubah meskipun terjadi perubahan jumlah produksi, sedangkan biaya variabel (variable cost) adalah biaya yang nilainya berubah seiring dengan perubahan jumlah produksinya. Menurut Soekartawi (2006), penerimaan (revenue) yaitu perkalian antara jumlah produksi yang diperoleh dengan harga jual produk. Dalam hal ini, penerimaan dikelompokkan menjadi 2, yakni penerimaan kotor dan penerimaan bersih. Penerimaan kotor (bruto) adalah hasil penjualan produk sebelum dikurangi total biaya (biaya tetap dan biaya 
variabel), sedangkan penerimaan bersih atau keuntungan/pendapatan (income) adalah hasil penjualan setelah dikurangi total biaya dan pajak penghasilan usaha $(\mathrm{PPh})$.

a. Biaya (Cost)

Menurut Mubyarto (2003), total biaya diperoleh dari formula berikut ini:

$\mathbf{T C}=\mathbf{T F C}+\mathbf{T V C}$

Keterangan:

$\mathrm{TC}=$ Biaya total $($ Total Cost $)(\mathrm{Rp})$

TFC = Total biaya tetap (Total Fixed Cost) (Rp)

TVC $=$ Total biaya variabel $($ Total Variable Cost) (Rp)

b. Penerimaan (Revenue)

Menurut Mubyarto (2003), besarnya jumlah penerimaan dapat diperoleh dari formula berikut ini:

$\mathbf{T R}=\mathbf{P} \times \mathbf{Q}$

Keterangan:

$\mathrm{TR}=$ Total penerimaan (Total Revenue) (Rp)

$\mathrm{P} \quad=$ Harga produk $($ Price $)(\mathrm{Rp})$

$\mathrm{Q} \quad=$ Jumlah produk (Quantity) (unit)

c. Pendapatan (Income)

Menurut Mubyarto (2003), besarnya nilai pendapatan atau keuntungan dihitung melalui formula sebagai berikut:

$\boldsymbol{\pi}=\mathbf{T R}-\mathbf{T C}$

Keterangan:

$\pi=$ Pendapatan $/$ keuntungan (Income)

(Rp)

$\mathrm{TR}=$ Total penerimaan (Total Revenue)

(Rp)

$\mathrm{TC}=$ Biaya total (Total Cost $)(\mathrm{Rp})$

d. Efisiensi Usaha

Efisiensi usaha adalah perbandingan antara penerimaan dan biaya yang diperoleh oleh suatu usaha dan menunjukkan jumlah nilai penerimaan lebih besar dibandingkan dengan total biayanya. Menurut Hernanto (2003), R/C ratio dapat diperoleh dari formulasi sebagai berikut:

$\mathrm{R} / \mathrm{C}$ ratio $=\frac{T}{T}$

Keterangan:

$\mathrm{R} / \mathrm{C}$ ratio $=$ Perbandingan antara penerimaan dan biaya

TR= Total penerimaan $($ Total

Revenue) (Rp)

$\mathrm{TC}=$ Biaya total $($ Total Cost $)(\mathrm{Rp})$

Apabila:
$\mathrm{R} / \mathrm{C}$ ratio $>1$ : Berarti usaha yang dijalankan secara ekonomis efisien atau memberikan menguntungkan.

$\mathrm{R} / \mathrm{C}$ ratio $<1$ : Berarti usaha yang dijalankan secara ekonomis tidak efisien atau tidak memberikan keuntungan.

$\mathrm{R} / \mathrm{C}$ ratio $=1$ : Berarti usaha mengalami titik impas (tidak untung dan tidak rugi).

\section{Hasil dan Pembahasan}

Riset aksi ini merupakan bagian dari kegiatan program iptek bagi masyarakat (IbM) dilakukan melalui beberapa tahap kegiatan. Kegiatan diawali dengan sosialisasi program, pemilihan alat dan bahan, praktek perbaikan produksi dan pengemasan, menghitung respond pelanggan, dan terakhir menghitung keuntungan ekonomi usaha setelah perbaikan. Masing-masing tahap merupakan proses timbal balik antara peneliti dan UKM sesuai dengan pendekatan riset aksi yang dipilih.

\subsection{Proses Sosialisasi}

Sosialisasi meliputi intervensi-intervensi apa yang akan dilakukan serta konsekwensikonsekwensi terhadap keberlangsungan produksi yang telah rutin dilakukan. Sosialisasi juga dilakukan intervensi-intervensi apa yang dilakukan setelah sosialisasi dan berbagai kemungkinnannya. Dari sosialisasi ini diharapkan pelaku UKM mempersiapkan sejak dini apa-apa yang akan dikerjakan sehingga tidak mengganggu rutinitas mereka.

a. Mitra menyediakan sarana prasarana kegiatan yang meliputi tempat, listrik, air, dan bahan baku berupa susu segar.

b. Mitra berpartisipasi langsung mulai dari persiapan hingga aplikasi teknologi yaitu melakukan kegiatan produksi sesuai dengan teknologi yang di introduksikan oleh Tim Pelaksana IbM Selain itu kelompok mitra juga mempunyai tanggungjawab dalam memelihara dan mengelola hasil-hasil program baik berupa alat/mesin, bahan maupun produk dengan sebaik-baiknya serta memberikan laporan kemajuan usaha secara berkala kepada Tim Pelaksana Program.

Tahap Evaluasi dan Desiminasi. Pada tahap ini mitra berpartisipasi dalam membantu memonitor dan evaluasi pelaksanaan kegiatan, mengidentifikasi permasalahan yang dihadapi serta mengukur indicator yang harus dicapai 
Evaluasi Program ini secara keseluruhan dilakukan pada awal dan akhir program. Evaluasi dilakukan terhadap dua indikator yaitu: (1) pengetahuan dan pemahaman (Knowledge), (2) keahlian/ketrampilan (skill). Tahapan evaluasi Program adalah sebagai berikut:

1) Awal program, dilakukan pre test untuk mengetahui tingkat pengetahuan, pemahaman, skill dan kesadaran dasar (basic) yang dimiliki oleh mitra sasaran sebelum mendapatkan Program. Akhir program, dilakukan post test, untuk mengetahu sejauh mana tingkat keberhasilan program dalam meningkatkan dua indikator kinerja yaitu knowledge dan skill secara positif dan signifikan. Indikator keberhasilan berupa kenaikan nilai, jika nilai antara post test dan pre test semakin besar maka hasil yang dicapai semakin baik. Kriteria evaluasi yang digunakan yaitu :

a) Nilai $\leq 40 \%$ : pelatihan kurang berhasil (ketrampilan peserta kurang).

b) Nilai $41 \%-70 \%$ : pelatihan cukup berhasil (ketrampilan peserta cukup).

c) Nilai $>70 \%$ : pelatihan berhasil baik (ketrampilan peserta meningkat tajam).

Kegiatan pelatihan dan percontohan pada penerapan ipteks ini, indikator keberhasilan yang diharapkan berupa $70 \%$ mitra sasaran dapat menerapkan teknologi. Kegiatan ini nilai mitra Ukm Sehati yoghut diatas $70 \%$. Hal tersebut menunjukan pelatihan berhasil baik sosialisasi dan pembekalan ketrampilan peserta meningkat tajam.

2) Untuk mengukur peningkatan volume usaha serta omzet usaha dengan membandingkan volume usaha dan omzet usaha sebelum dan sesudah Pelaksanaan program.

Kegiatan pelatihan manajemen umkm dan pemasaran dilaksanakan sebagai penguat dalam kegiatan usaha mitra. Manajemen dititik beratkan pada pengelolaan bahan baku, proses produksi dan manajemen keuangan melalui pembukuan. Perluasan jaringan pemasaran dilakukan dengan menggunakan system pemasaran online dengan menggunakan media social dan fanpage facebook maupun istagram dengan nama ID sehati yogurt cara ini dianggap efektif karena banyak costumer baru dan perluasan wilayah penjualan tidak hanya di purwokerto saja tetapi di luar daerah purwokerto.
Sedangkan Untuk mengetahui cash and flow pendapatan serta pengeluaran Ukm sehati yogurt diberikan pelatihan pembukuan, mitra belajar bagaimana cara pembukuan secara tepat sehingga Ukm bisa mengetahui pendapatan Netto dan keuntungan bersih baik dalam harian, mingguan atau bulanan, pelatihan ini dirasa penting karena mitra sebelum nya tidak menerapkan pembukuan dengan baik, hasil penjualan masih tercampur dengan keuangan pribadi. Pelatihan ini memberikan edukasi mengelola arus kas, memberikan pendekatan pengelolaan keuangan yang praktikal dan sesuai unit usaha kecil yang pengelolaa keuangan sederhana sehingga mitra mudah untuk mengadopsi. Dengan mengetahui aliran kas operasional meliputi penerimaan dan pengeluaran kas $\mathrm{ukm}$ secara riil yang berkaitan penerimaan hasil penjualan tunai, hasil pengumpulan utang (konsinasi) dan penerimaan laba. Dengan menerapkan pembukuan dengan baik kedua UKM sekarang bisa menghitung keuntungan bersih setiap hari dan pembukuan lebih tertata rapi hal tersebut menjadi salah satu factor kesuksesan suatu usaha.

\subsection{Proses pemilihan alat dan bahan}

Pemilihan alat dan bahan dibantu oleh peneliti melalui program Iptek Bagi Masyarakat (IbM) yang dibiayai dari Hibah Kemenristek Dikti. Bantuan alat dan bahan disesuaikan dengan kebutuhan UKM sehingga membantu investasi modal. Riset ini sejak awal dilakukan proses penambahan kapasitas produksi sehingga penggunaan alat tersebut membantu didalam proses peningkatan produksi dan perbaikan dilakukan pada kemasan dan penambahan beberapa varian rasa yogurt baru sesuai dengan kesepakatan dan potensi pasar.

Dengan adanya bantuan freezer dan Cup sealer sangat membantu mitra yang tadinya harus produksi setiap hari dengan volume skala kecil yaitu $3 \mathrm{~L}$ susu sekarang dengan adanya freezer bisa menampung lebih banyak susu yaitu sampai 10-15 L serta produksi seminggu bisa produksi 3 kali dengan skala yang lebih banyak dan menghemat tenaga, dan waktu lainnya bisa digunakan untuk promosi dan dropsite kepada reseler maupun costumer itu artinya adanya pengaruh positif dengan sentuhan teknologi membantu mitra naik kelas dan produksi meningkat itu terbukti dari meningkatnya produksi dan penjualan setiap harinya dan skala penjualan jangkauan lebih luas. 
Dengan adanya bantuan cup sealer membantu mitra untuk mengemas dalam bentuk cup dengan ukuran volume yang lebih kecil,menjangkau pasar yg lebih luas dengan berbagai lapisan masyarakat, terobosan ini bertujuan menjaring costumer dan meningkatkan daya beli. Menawarkan sebuah solusi dengan volume dan harga lebih murah sehingga semua lapisan masyarakat bisa menikmati yoghut dengan harga ekonomis, hal tersebut terbukti dengan meningkatkan permintaan dan daya beli dari mitra sehati yogurt.

Tujuan pemberian alat inkubator ini diharapkan pada mitra bisa meningkatkan produksi yoghut, terutama pada saat susu di inkubasikan, selama ini mitra masih menggunakan alat sederhana dari steroform sehingga pada waktu inkubasi hanya bisa dengan volume sedikit dan perlu berulang ulang menunggu antrian inkubasi, hal tersebut tidak efisien disamping itu standar higienis kurang terjaga dan sering kali susu terkontaminasi mengakibatkan susu menjadi rusak hal tersebut menyebabkan mitra merugi, dengan sentuhan teknologi dan pendampingan mitra terbantu dalam hal produksi dengan waktu yg lebih efisien karena alat ini secara otomatis akan berhenti disaat suhu mencapai $45^{\circ} \mathrm{C}$.

\subsection{Proses Perbaikan Rasa dan Kemasan}

Perbaikan proses produksi dan pengemasan dilakukan dengan menambahan citarasa dengan berbagai varian rasa dan pengkayaan dengan nutrisi berbahan alami. Dari UKM yoguth sehati yang tadinya hanya 4 varian rasa original, plain, strawberry, melon setelah ada pendampingan meningkat menjadi 8 varian rasa seperti strawberry, melon,anggur, original, plain, jeruk, durian dan leci, Sedangkan untuk cony yoguth mengalami perbaikan varian rasa dari 3 varian rasa yaitu original, strawberry, anggur menjadi 6 varian rasa yaitu melon,strawberry, Anggur, jeruk,original,leci. Dengan adanya penambahan varian rasa meningkatkan penjualan ditandai dengan meningkatnya produksi susu dari 5 L/hari menjadi $25 \mathrm{~L} /$ hari hal tersebut sesuai dengan peryataan Jannah et al., 2014 menyatakan Citarasa asam yogurt yang berasal dari laktosa dalam susu yang diubah menjadi asam laktat oleh bakteri asam laktat selama proses fermentasi berlangsung akan meningkatkan keasaman susu, sehingga menyebabkan yogurt memiliki rasa asam.

Perbaikan kemasan dan menambah jenis ukuran varian kemasan meningkatkan umur simpan dengan produk frozen yoghurt mampu meningkatkan minat beli konsumen. Kemasan merupakan bagian penting dalam suatu produk sehingga akan memberikan kontribusi pada peningkatan produksi pada UKM secara kompetitif dan menyakinkan konsumen mereka mendapatkan produk yang berkualitas sehingga konsumen akan membeli dan menyukainya kemudian akan berpengaruh terhadap costmumer akan membelinya kembali.

Untuk perbaikan kemasan dirancang memiliki keunikan yang tidak banyak ditemukan pada produk pesaing sehingga produk yoguth UKM sehati yoguth memiliki ciri khas dan mudah diingat konsumen. Fungsi dalam pemilihan kemasan yang tepat berpengaruh terhadap masa simpan, pencegahan tercemarnya bahan makanan oleh bakteri, mikroba bahkan suhu udara yang dapat menyebabkan perubahan rasa maupun pencemaran terhadap bahan minuman tersebut.

Salah satu syarat packaging yang baik salah satu tidak ada toksin sehingga UKM memilih packaging standar food grade salah satu syarat bahan kemasan yang paling penting untuk suatu produk makanan tidak boleh mengandung zat yang dapat menganggu kesehatan manusia. Selain itu, kegiatan pelatihan manajemen umkm dan pemasaran dilaksanakan sebagai penguat dalam kegiatan usaha di kedua mitra. Manajemen dititik beratkan pada pengelolaan bahan baku, proses produksi dan manajemen keuangan melalui pembukuan. Perluasan jaringan pemasaran dilakukan dengan menggunakan system pemasaran online dengan menggunakan media sosial dan fanpage facebook.

\subsection{Respon Konsumen}

Respond pelanggan dapat dilihat dari meningkatkan kesukaan konsumen terhadap yoghurt karena perbaikan sifat sensorik dengan penambahan cita rasa. Pengemasan secara teoritik memiliki efek cognitive (Suzianti, et. al., 2015) sangat penting bagi konsumen karena kemasan adalah kesan pertama yang muncul pada produk. Jika kemasan memberikan kesan positif, maka seseorang lebih berpotensi membeli daripada tidak. Kemasan yang buruk ternyata juga memberikan dapat negative pada nilai Yougurt atau bahkan dapat menyebabkan penurunan nilai dari yogurt tersebut (Ferreira et. al., 2016). Secara acak dilakukan penilaian terhadap hasil kemasan baru, baik pelanggan maupun tetangga sekitar dan pemilik UKM sendiri menunjukan tanggapan yang positif.

Ukuran volume yang lebih kecil ,menjangkau pasar yg lebih luas dengan berbagai 
lapisan masyarakat, terobosan ini bertujuan menjaring costumer dan meningkatkan daya beli. Menawarkan sebuah solusi dengan volume dan harga lenih murah sehingga smua lapisan masyarakat bisa menikmati yogurt dengan harga ekonomis, hal tersebut terbukti dengan meningkatkan permintaan dan daya beli dari mitra sehati yogurt khususnya pada kemasan ekonomis.

\subsection{Analisis Pendapatan}

UKM Yogurt Sehati yang terletak di Kecamatan Purwokerto Utara Kabupaten Banyumas telah berproduksi selama lebih dari 2 tahun dan telah memberikan kontribusi bagi peningkatan pendapatan mitra. Untuk menguji tingkat keberhasilan usaha yogurt tersebut maka dilakukan analisis tentang pendapatan dan tingkat efisiensi usahanya. Analisis pendapatan merupakan selisih antara hasil penerimaan dengan total biaya yang dikeluarkan selama masa produksi. Dalam hal ini, analisis pendapatan dihitung selama 1 tahun masa produksi dan UKM Yogurt Sehati memproduksi produk yogurtnya setiap hari.

\section{Biaya Total (Total Cost)}

Biaya yang dikeluarkan dalam UKM Yogurt Sehati terbagi menjadi 2 yakni biaya tetap (fixed cost) dan biaya variabel (variable cost). Berikut ini disajikan rincian biaya tetap yang dikeluarkan oleh UKM Yogurt Sehati:

Tabel 1. Komponen Biaya Tetap (Fixed Cost) UKM Yogurt Sehati, 2017

\begin{tabular}{clr}
\hline No. & $\begin{array}{c}\text { Biaya } \\
\text { Tetap }\end{array}$ & $\begin{array}{c}\text { Jumlah } \\
\text { (Rp/tahun) }\end{array}$ \\
\hline 1. & Pajak PBB & 800.000 \\
\hline 2. & $\begin{array}{l}\text { Penyusutan } \\
\text { peralatan }\end{array}$ & 7.088 .500 \\
\hline & Jumlah & $\mathbf{7 . 8 8 8 . 5 0 0}$ \\
\hline
\end{tabular}

Berdasarkan pada Tabel 1, dapat diketahui jika biaya tetap (fixed cost) terdiri dari biaya Pajak Bumi Bangunan (PBB) dan biaya penyusutan peralatan. Dalam hal ini, biaya penyusutan peralatan diperoleh melalui metode garis lurus. Peralatan yang dipergunakan dalam usaha yogurt diantaranya kulkas, freezer, mesin inkubator, termometer, timbangan, panci, gelas ukur, mixer, kompor gas, cooler box, box inkubasi, ice gel, saringan, dan sebagainya. Total biaya tetap yang diperlukan pada UKM Yogurt Sehati selama 1 tahun masa produksi adalah sebesar Rp 7.888.500. Selanjutnya berikut ini disajikan rincian biaya variabel (variable cost) yang dikeluarkan oleh UKM Yogurt Sehati:

Tabel 2. Komponen Biaya Variabel (Variable Cost) UKM Yogurt Sehati, 2017

\begin{tabular}{|c|c|c|c|c|c|c|}
\hline No. & $\begin{array}{c}\text { Biaya } \\
\text { Variabel }\end{array}$ & Kebutuhan & $\begin{array}{c}\text { Harga } \\
\text { (Rp/satuan) }\end{array}$ & $\begin{array}{l}\text { Jumlah } \\
\text { (Rp/hari) }\end{array}$ & $\begin{array}{c}\text { Jumlah } \\
\text { (Rp/bulan) }\end{array}$ & $\begin{array}{c}\text { Jumlah } \\
\text { (Rp/tahun) }\end{array}$ \\
\hline 1. & Susu & $25 \mathrm{~L}$ & 7.500 & 187.500 & 5.625 .000 & 67.500 .000 \\
\hline 2. & Botol $250 \mathrm{ml}$ & 20 buah & 1.500 & 30.000 & 900.000 & 10.800 .000 \\
\hline 3. & Botol $1 \mathrm{~L}$ & 15 buah & 4.000 & 60.000 & 1.800 .000 & 21.600 .000 \\
\hline 4. & $\begin{array}{l}\text { Plastik } 100 \\
\text { mL }\end{array}$ & 500 buah & 70 & 35.000 & 1.050 .000 & 12.600 .000 \\
\hline 5. & Gula pasir & $10 \mathrm{~kg}$ & 25.000 & 250.000 & 7.500 .000 & 90.000 .000 \\
\hline 6. & Air & $45 \mathrm{~L}$ & 1.000 & 45.000 & 1.350 .000 & 16.200 .000 \\
\hline 7. & Label & 35 buah & 500 & 17.500 & 525.000 & 6.300 .000 \\
\hline 8. & TK & 2 orang & 60.000 & 120.000 & 3.600 .000 & 43.200 .000 \\
\hline 9. & Sirup essence & - & - & - & 100.000 & 36.000 .000 \\
\hline & Anti ragi & - & - & - & 50.000 & 18.000 .000 \\
\hline 11. & Starter & $200 \mathrm{~mL}$ & 150.000 & 150.000 & 150.000 & 54.000 .000 \\
\hline 12. & Listrik & - & - & 10.000 & 150.000 & 3.600 .000 \\
\hline & Gas & - & - & - & 200.000 & 1.800 .000 \\
\hline 14. & Plastik seal & 20 & - & - & 200.000 & 2.400 .000 \\
\hline 15. & $\mathrm{BBM}$ & - & - & - & 500.000 & 6.00 .000 \\
\hline \multicolumn{4}{|c|}{ Jumlah } & 1.060 .000 & 32.500 .000 & 390.000 .000 \\
\hline
\end{tabular}


Berdasarkan pada Tabel 2, dapat dilihat jika komponen biaya variabel pada UKM Yogurt Sehati terdiri dari susu segar, kemasan botol dan plastik, gula pasir, air, anti ragi, starter, sirup essence, listrik, gas, plastik seal, label, dan tenaga kerja (TK). Setiap hari mitra memproduksi susu segar sebanyak 25 liter dengan berbagai varian rasa dan kemasan (botol $250 \mathrm{~mL}$, botol $1 \mathrm{~L}$, dan plastik $100 \mathrm{~mL}$ ) dimana membutuhkan biaya variabel sekitar Rp 1.060.000/hari. Total biaya variabel (variable cost) yang dikeluarkan oleh UKM Yogurt Sehati selama 1 tahun masa produksi yaitu sebesar Rp 390.000.000. Biaya tersebut nilainya dapat berubah tergantung dari jumlah produksi usaha yogurt jika menerima pesanan-pesanan khusus. Oleh sebab itu, dapat dihitung nilai biaya total yang dikeluarkan UKM Yogurt Sehati sebagai berikut:

Pada Tabel 3 dapat dilihat jika jumlah biaya total yang dikeluarkan oleh UKM Yogurt selama 1 tahun masa produksi yakni sebesar Rp 397.885.500. Biaya tersebut terdiri dari total biaya tetap $\mathrm{Rp} 7.888 .500 /$ tahun dan total biaya variabel Rp 390.000.000/tahun.
Tabel 3. Komponen Biaya Tetap (Fixed Cost) UKM Yogurt Sehati, 2017

\begin{tabular}{c|cr}
\hline No. & Biaya Total & $\begin{array}{r}\text { Jumlah } \\
\text { (Rp/tahun) }\end{array}$ \\
\hline 1. & Total biaya tetap (TFC) & 7.888 .500 \\
\hline 2. & Total biaya variabel (TVC) & 390.000 .000 \\
\hline & Jumlah & $\mathbf{3 9 7 . 8 8 8 . 5 0 0}$ \\
\hline
\end{tabular}

Penerimaan (Revenue)

UKM Yogurt Sehati setiap harinya mampu menghasilkan produk Yogurt sebanyak 500 buah kemasan plastik $100 \mathrm{~mL}, 20$ botol kemasan 250 $\mathrm{mL}$, dan 15 botol kemasan $1 \mathrm{~L}$. Harga jual masingmasing produk yakni $\mathrm{Rp} 1.000$ untuk kemasan plastik, Rp 10.000 untuk botol $250 \mathrm{~mL}, \mathrm{Rp} 32.000$ untuk botol $1 \mathrm{~L}$ (rasa plain), dan Rp 37.000 untuk botol $1 \mathrm{~L}$ (varian rasa). Oleh sebab itu dapat dihitung besarnya omset UKM Yogurt Sehati dimana rincian penerimaannya dapat dilihat pada Tabel 4. :

Tabel 4. Komponen Penerimaan (Revenue) pada UKM Yogurt Sehati, 2017

\begin{tabular}{lccrrr}
\hline Kemasan & $\begin{array}{c}\text { Jumlah } \\
\text { (buah) }\end{array}$ & $\begin{array}{c}\text { Harga } \\
\text { (Rp/buah) }\end{array}$ & $\begin{array}{c}\text { Jumlah } \\
(\mathbf{R p} / \mathbf{h a r i})\end{array}$ & $\begin{array}{c}\text { Jumlah } \\
\text { (Rp/bulan) }\end{array}$ & \multicolumn{1}{c}{$\begin{array}{c}\text { Jumlah } \\
\text { (Rp/tahun) }\end{array}$} \\
\hline Plastik 100 mL & 500 & 1.000 & 450.000 & 13.500 .000 & 162.000 .000 \\
\hline Botol 250 mL & 20 & 10.000 & 200.000 & 6.000 .000 & 72.000 .000 \\
\hline Botol 1 L: & & & & & \\
a. Plain & 5 & 32.000 & 160.000 & 4.800 .000 & 57.600 .000 \\
b. Varian rasa & 10 & 37.000 & 370.000 & 11.100 .000 & 133.200 .000 \\
\hline & Jumlah & & $\mathbf{1 . 1 8 0 . 0 0 0}$ & $\mathbf{3 5 . 4 0 0 . 0 0 0}$ & $\mathbf{4 2 4 . 8 0 0 . 0 0 0}$ \\
\hline
\end{tabular}

Berdasarkan pada Tabel 3, dapat diketahui jika besarnya nilai penerimaan kotor (revenue) yang diperoleh UKM Yogurt Sehati selama 1 tahun masa produksi yakni sebesar Rp 424.800.000. Besarnya nilai tersebut tidak terlepas dari adanya perbaikan kemasan produk yogurt yang telah menarik hati para konsumen baik konsumen aktual maupun potensial.

\section{Pendapatan (Income)}

Berdasarkan rincian komponen biaya dan penerimaan yang telah dijabarkan di atas, maka dapat dihitung besarnya nilai pendapatan atau penerimaan bersih atau keuntungan yang diterima oleh UKM Yogurt Sehati. Berikut ini disajikan perhitungan pendapatannya:
Tabel 5. Komponen Pendapatan (Income) pada UKM Yogurt Sehati, 2017

\begin{tabular}{lr}
\hline \multicolumn{1}{c}{ Uraian } & \multicolumn{1}{c}{$\begin{array}{c}\text { Nilai } \\
\text { (Rp/tahun) }\end{array}$} \\
\hline Total biaya tetap (TFC) & 7.888 .500 \\
\hline Total biaya variabel (TVC) & 390.000 .000 \\
\hline Total biaya (TC) & 397.888 .500 \\
\hline Penerimaan (TR) & 424.800 .000 \\
\hline $\begin{array}{l}\text { Pendapatan/keuntungan } \\
\text { sebelum pajak }\end{array}$ & $\mathbf{2 6 . 9 1 1 . 5 0 0}$ \\
\hline Pajak 0,5 \% & 134.558 \\
\hline $\begin{array}{l}\text { Pendapatan/keuntungan } \\
\text { setelah pajak }\end{array}$ & $\mathbf{2 6 . 7 7 6 . 9 4 3}$ \\
\hline
\end{tabular}

Pada Tabel 5 dapat dilihat jika besarnya biaya total yang dikeluarkan UKM Yogurt Sehati sebesar Rp 397.885.500/tahun dengan total penerimaan kotor yang diperoleh sebesar Rp 
424.800.000/tahun. Oleh karena itu, jumlah pendapatan/keuntungan/penerimaan bersih sebelum dikenakan tarif pajak penghasilan usaha $(\mathrm{PPh})$ yakni sebesar Rp 26.911.500/tahun. Namun, dikarenakan UKM Yogurt memiliki omset penjualan tahunan > Rp 300 juta maka berdasarkan UU No.36 Tahun 2008 Pasal 2 tentang Pajak Penghasilan diperoleh kesimpulan jika usaha yogurt tersebut harus dikenakan tarif pajak yakni $0,5 \%$ dari jumlah penerimaan tahunan sehingga diperoleh tarif pajak sebesar Rp 134.558/tahun. Selanjutnya, diperoleh jumlah pendapatan/keuntungan/pendapatan bersih setelah dipotong tarif pajak yakni sebesar Rp 26.776 .943 selama 1 tahun masa produksi atau sebesar $\mathrm{Rp}$ 2.231.412 per 1 bulan masa produksi.

\section{Efisiensi Usaha}

Efisiensi usaha digunakan untuk mengidentifikasi tingkat produktivitas usaha tersebut terhadap biaya-biaya yang dikeluarkan selama masa produksi. Efisiensi yang tinggi mencerminkan kemampuannya dalam menghasilkan suatu produk dan mampu memberikan tingkat keuntungan. Dalam hal ini, untuk mengetahui nilai efisiensi UKM Yogurt Sehati diperoleh dengan membagi jumlah penerimaan (Total Revenue) dengan besarnya biaya total (Total Cost) yang dikeluarkan selama masa produksi 1 tahun.

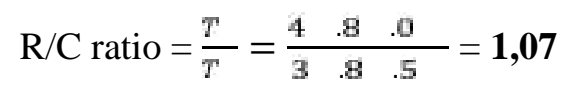

Dari hasil analisis diatas maka dapat diperoleh niai R/C ratio UKM Yogurt Sehati sebesar 1,07. Berdasarkan kaidah efisiensi usaha maka dapat disimpulkan jika UKM Yogurt Sehati dikatakan efisien dan memberikan keuntungan karena memiliki nilai 1,07 (R/C ratio > 1) dimana artinya bahwa setiap $\mathrm{Rp} 1.000$ atas biaya keseluruhan yang dikeluarkan mitra akan memberikan penerimaan sebesar Rp 1.700. UKM Yogurt Sehati yang telah berproduksi lebih dari 2 tahu tersebut merupakan usaha yang layak dijalankan karena dapat memberikan jumlah penerimaan yang lebih besar dibandingkan dengan biaya total yang dikeluarkan oleh usaha tersebut.

\section{Kesimpulan}

a. Kegiatan pelatihan mampu meningkatkan pengetahuan dan ketrampilan mitra.

b. Terjadi peningkatan volume produksi yogurt rata-rata dari $5 \mathrm{~L}$ per hari meningkat menjadi 25 L perhari dengan variasi produk bermacam-macam.

c. Perubahan kemasan produk berpengaruh positif terhadap persepsi dan minat konsumen yogurt.

d. Berdasarkan hasil perhitungan, UKM Yogurt Sehati setiap 1 tahun masa produksi mengeluarkan biaya total (biaya tetap dan biaya variabel) sebesar $\mathrm{Rp}$ 397.888.500/tahun, sedangkan hasil penerimaan yang diperoleh sebesar $\mathrm{Rp}$ 424.800.000/tahun.

e. UKM Yogurt mendapatkan penerimaan bersih/keuntungan sebesar $\mathrm{Rp} \quad \mathrm{Rp}$ 26.776.943 selama 1 tahun masa produksi atau sebesar $\mathrm{Rp} 2.231 .412$ per 1 bulan masa produksi.

f. Analisis efisiensi usaha menunjukkan nilai $\mathrm{R} / \mathrm{C}$ ratio sebesar 1,07 dimana artinya setiap Rp 1.000 atas biaya keseluruhan yang dikeluarkan maka akan memberikan penerimaan sebesar Rp 1.070 kepada UKM Yogurt Sehati sehingga usaha tersebt layak untuk dijalankan karena jumlah penerimaan yang lebih besar dari biaya total yang dikeluarkan selama masa produksi.

\section{Ucapan Terimkasih}

Penulis mengucapkan terimkasih sebesarbesarnya kepada Chesty Zulfanida selaku pemilik UKM Yogurt Sehati atas kerjasamanya dalam program IbM, Ketua LPPM Universitas Peradaban yang telah memfasilitasi kegiatan ini, dan Direktorat Penelitian dan pengabdian Masyarakat (DRPM) Kemenristekdikti yang telah memberikan pembiayaan dalam kegiatan ini melalui Skil IbM Tahun Anggaran 2017.

\section{Daftar Pustaka}

Arioui, F., Ait Saada, D., \& Cheriguene, A. (2017). Physicochemical and sensory quality of yogurt incorporated with pectin from peel of Citrus sinensis. Food science \& nutrition, 5(2), 358-364.

Freitas, M. (2017). The benefits of yogurt, cultures, and fermentation. The Microbiota in Gastrointestinal Pathophysiology, 209223. doi:10.1016/b978-0-12-8040249.00024-0.

Hernanto, F. 2003. Ilmu Usaha Tani. Jakarta: Penebar Swadaya. 
Jannah, A.M., A.M. Legowo, Y.B. Pramono, A.N. Al-Baarri, dan S.B.M. Abduh. Total Bakteri Asam Laktat, pH, Keasaman, Citarasa dan Kesukaan Yogurt Drink dengan Penambahan Ekstrak Buah Belimbing. Jurnal Aplikasi Teknologi Pangan 3 (2) : 7-11.

Koswara, S. 2009. Teknologi Pembuatan Yoghurt. eBookPangan.com.

Mistura, L., D’Addezio, L., Sette, S., Piccinelli, R., \& Turrini, A. (2016). Diet quality of Italian yogurt consumers: an application of the probability of adequate nutrient intake score (PANDiet). International journal of food sciences and nutrition, 67(3), 232-238.

Meng, J. J., Qian, J., Jung, S. W., \& Lee, S. J. (2018). Practicability of TTI application to yogurt quality prediction in plausible scenarios of a distribution system with temperature variations. Food science and biotechnology, 27(5), 1333-1342.

Mubyarto. 2003. Pengantar Ekonomi Pertanian. Jakarta: LP3ES.

O'Brien, Rory. 2002. An Overview of the Methodological Approach of Action Research. Faculty of Information StudiesUniversity of Toronto. USA.

Rahayu, N. S., \& Indrawati, S. (2014). IbM Kelompok Usaha Produk Olahan Susu Segar Di Dusun Boyong Desa Hargobinangun, Sleman Yogyakarta. Asian Journal of Innovation and Entrepreneurship, 3(03), 160-169.

Resnawati, H. 2015. Kualitas Susu Pada Berbagai Pengolahan dan Penyimpanan. Semiloka Nasional Prospek Industri Sapi Perah Menuju Perdagangan Bebas - 2020.

Soekartawi. 2006. Analisis Usaha Tani. Jakarta: UI Press.

Suzianti, A., Rengkung, S., Nurtjahyo, B., \& Al Rasyid, H. (2015). An analysis of cognitive based design of yogurt product packaging. Int. J. Technol, 6(4), 659.

Zhao, L., Feng, R., Ren, F., \& Mao, X. (2018). Addition of buttermilk improves the flavor and volatile compound profiles of low-fat yogurt. LWT, 98, 9-17. doi:10.1016/j.lwt.2018.08.029
Zhu, Y., Wang, H., Hollis, J. H., \& Jacques, P. F. (2015). The associations between yogurt consumption, diet quality, and metabolic profiles in children in the USA. European journal of nutrition, 54(4), 543-550. 